\title{
Is there a link between the type of habitat and the patterns of abundance of Holothurians in shallow rocky reefs?
}

\author{
Fernando Tuya ${ }^{1}$, José Carlos Hernández ${ }^{2} \&$ Sabrina Clemente ${ }^{2}$
}

${ }^{1}$ : School of Natural Sciences, Centre for Ecosystem Management, Edith Cowan University, 100 Joondalup Drive, Joondalup, 6027 WA, Australia

${ }^{2}$ : Department of Animal Biology (Marine Sciences), University of La Laguna, La Laguna, 38206, Canary Islands, Spain

Key words: holothurians, habitat, rocky reefs, barrens, sea urchins, Canary Islands

This paper has not been submitted elsewhere in identical or similar form, nor will be during the first three months after its submission to Hydrobiologia. 


\section{Abstract}

The presence of a mosaic of habitats, largely determined by sea urchin grazing, across shallow rocky reefs may potentially influence in differences in the distribution patterns of invertebrates. The aim of this paper was to assess, using a correlative approach, whether the type of habitat influences the abundance patterns of holothurians in the eastern Atlantic. We hypothesized that abundances of large $(>10 \mathrm{~cm})$ holothurians varied among four types of habitat (3 vegetated habitats with low abundances of the sea urchin D. antillarum versus 'barrens' with hyperabundances of sea urchins), and that these differences were consistent at a hierarchy of spatial scales, including two islands and several replicated sites within each type of habitat and island. Three species of large holothurians were found, accounting for a total of 300 specimens. We found remarkable differences in abundances of holothurians between the 'barrens' and the three vegetated habitats. This pattern was strongest for the numerically dominant species, Holothuria sanctorii. Total abundances of holothurians were between 5 - 46 times more abundant in 'barrens' compared with the vegetated habitats. Inter-habitat differences were species-specific with some inconsistent patterns from one island to the other. The total abundances of holothurians tended to increase with the abundance of sea urchins within 'barrens'. Our study suggests that there may be a link, at least for the dominant species Holothuria sanctorii, between the distribution and abundances of large holothurians and the habitat across shallow-waters of the eastern Atlantic. 


\section{Introduction}

Sea urchins can play an important role in the structure of coastal communities, by transforming large shallow rocky reefs covered by erect algae into overgrazed substrates dominated by encrusting coralline algae, so called 'barrens' (Lawrence, 1975; Andrew \& Underwood, 1989; Benedetti-Cecchi et al., 1998; Sala et al., 1998; Pinnegar et al., 2000; Shears \& Babcock, 2003). These 'barrens' are a semi-global phenomenon (Lawrence, 1975; Mann, 1982; Sala et al., 1998; Knowlton, 2004), and generally support lower biodiversity and biomass than nearby vegetated areas (Behrens \& Lafferty, 2004; Graham, 2004, and references therein).

In the eastern Atlantic, the foraging behavior of the long-spined black sea urchin, Diadema aff. antillarum Phillipi, produces a halo of barren habitat surrounding crevices, which expands to include all the available rocky substrate where urchins attain high densities (> 8 ind $\mathrm{m}^{-2}$, Tuya et al., 2004). As a result, mosaics of alternate organizational states on subtidal rocky reefs (vegetated versus unvegetated = urchinproduced barren systems) occur.

Benthic grazers can transform a great part of the consumed algae (up to 70\%) to detritical fecal matter (Vadas, 1977; Koike et al., 1987; Frantzis \& Gremare, 1992; Lison de Loma et al., 2000; Mills et al., 2000; Mamelona \& Pelletier, 2005). Urchin fecal pellets might constitute a source of fresh POM comprised of tissues of almost intact cells, and containing more macro- and micronutrients than POM from dead algae (Lawrence, 1976; Wotton, 1994; Lawrence \& Klinger, 2001; Levinton et al., 2002; Mamelona \& Pelletier, 2005). Consequently, some benthic grazers might form a trophic link between algae production and the feeding of detritivores. In particular, sea urchins could act as a significant source of POM; their fecal POM has a high potential of energy 
transfer to other organisms inhabiting rocky reefs (Mukai \& Nojima, 1985; Koike et al., 1987; Mamelona \& Pelletier, 2005).

One group of benthic invertebrates that is potentially affected by changes in the availability of POM in the benthos is holothurians (Ginger et al., 2001). Holothurians are deposit feeders. These animals obtain nutrients from the sediments in the form of organic detritus of vegetal and animal origin, fecal material and micro-organisms (bacteria and micro-algae) (Yingst, 1976; Massin, 1982; Moriarty, 1982; Uthicke, 2001). As a result, holothurians play an important role in reclying organic matter from within the substrate.

The presence of a mosaic of different habitats on shallow rocky reefs could potentially influence the distribution and abundance patterns of shallow-water holothurians. The aim of this paper was to assess whether there may be a relation between the type of habitat on shallow rocky reefs (explicitly 'vegetated' systems with low abundances of sea urchins versus 'barrens' with hyperabundances of sea urchins), and the patterns of abundance of holothurians. More specifically, we hypothesized (i) that abundances of large $(>10 \mathrm{~cm})$ holothurians varied among four types of habitat (3 vegetated habitats defined on the basis of their architecture versus 'barrens'), and (ii) that these differences were consistent at a hierarchy of spatial scales, including two adjacent islands and several sites per habitat within each island. In particular, we predicted that the potential increase in the availability of POM associated with hyperabundances of sea urchins in 'barrens' may increase the abundances of holothurians, or at least affect some species.

\section{Materials and methods}

Area of study and sampling design 
The study was carried out on basaltic rocky bottoms between 3 to $10 \mathrm{~m}$ of depth at Gran Canaria and Tenerife islands (the Canarian Archipelago, $28^{\circ} \mathrm{N}$, eastern Atlantic Ocean), during June to November 2005. In this area, the distribution of benthic assemblages along the bathymetric axis shows a clear vertical zonation pattern. Within the shallowest photophilic zone, extensive stands of algal assemblages make up the dominant community (hereafter called 'algal stands') (Tuya \& Haroun, 2006), with few major grazers such as sea urchins. Intensive grazing by hyperabundances of Diadema antillarum produces clear interfaces between these shallow water algal stands and areas devoid of vegetation, resulting in the existence of extensive 'barrens', which occupy the deepest part of rocky reefs.

Canopy-forming algae were categorized into three morphological groups, by taking into account the algal form groups reported in the literature (Steneck \& Dethier, 1994), especially those from the nearby Mediterranean (Ruitton et al., 2000), as well as our own experience in the study area (Tuya \& Haroun, 2006). Turf algae (hereafter TA) consist of small cushion-shaped and filamentous species, usually $<5 \mathrm{~cm}$ in height, such as Codium spp., Colpomenia sinuosa, Dasycladus vermicularis and, principally, Lobophora variegata. Bush-like algae (hereafter BA) are sheet-shaped, jointed noncrustose calcareous species (e.g. Asparagopsis spp., Corallina elongata, Dyctiota spp., Padina pavonica, Stypocaulon scoparium, Stypopodium zonale, Taonia atomaria, Zonaria tournefortii, etc.), from 1 to $15 \mathrm{~cm}$ in height. Corticated, large, brown macrophytes (hereafter BM) are erect, frondose, coarsely-branched fucoid species (the genera Cystoseira and Sargassum), usually $>15 \mathrm{~cm}$ in height, and in general forming low diversity algal stands. 
We selected 3 different sites, several kilometres apart, for each type of habitat at each island. As a result, a total of 24 sites were surveyed as spatial replicates of the four defined habitats (3 'vegetated' habitats and the 'barrens').

\section{Sampling and data analysis}

At each site, a SCUBA-diver quantified in situ the abundances of all large ( $>10$ $\mathrm{cm}$ ) holothurians and adult (test diameter $>1 \mathrm{~cm}$ ) Diadema antillarum sea urchins in ten, non-overlapping, 1 x 1 m quadrats. Quadrats, several meters apart, were haphazardly laid out. Since holothurians remain hidden in the rocky substrate during daytime hours, but begin to merge following nightfall (Hammond, 1982), we decided to carry out all diving during nighttime with the help of underwater lamps. To eliminate the potential effect of the 'habitat complexity' on the spatial patchiness of holothurians, all quadrats were deployed on smooth horizontal rocky surfaces, avoiding as much as possible the presence of structural 'elements' that potentially could increase the complexity of the substrate (pebbles, boulders, caves, crevices, etc).

Hypotheses were tested using multivariate and univariate procedures. To test for differences in the holothurian assemblage caused by the four types of habitat across the hierarchy of spatial scales, we used the semi-parametric, distance based, Permutational Multivariate Analysis of Variance (PERMANOVA; Anderson, 2004). Data were transformed to square root and analyses were based on Bray-Curtis dissimilarities. The PERMANOVA incorporated the following factors: (1) 'Habitat' (fixed factor with four levels) (2) 'Island' (random factor with two levels corresponding to each island, and orthogonal to the previous factor), and (3) 'Sites' (random factor with three levels, nested within the interaction between 'Islands' and 'Habitat'). PERMANOVA was used to partition variability and provide measures of multivariate variability at different 
scales in the structured design in a manner analogous to univariate partitioning using ANOVA (Anderson \& Millar, 2004). When appropriate, pairwise a posteriori comparisons were executed using permutations (Anderson, 2004). A mixed model ANOVA was applied to test for significant differences in the mean abundances of each species of holothurians with the same factors outlined above. Hence, ANOVAs tested the same hypotheses described above for multivariate data, but in a univariate context. When the factor 'Habitat' was significant, pairwise $a$ posteriori SNK tests were used to determinate the nature of the differences. Before analysis, the Cochran's test was used to check for homogeneity of variances. Although no transformation rendered variances homogeneous (Cochran's test, $\mathrm{p}<0.01$ ), the ANOVA was carried out as it is robust to heterogeneity of variances, particularly for large balanced experiments (Underwood, 1997). The significance level was thus set at the 0.01 level instead of 0.05 (Underwood, 1997).

We used a simple linear regression model to correlate the abundances of total holothurians and Diadema antillarum sea urchins within quadrats at the six 'barren' sites. To analyze the data 'as a whole', we normalized all data by dividing each value of abundance by the mean value of abundance at each particular site.

\section{Results}

Three species of large holothurians were found, accounting for a total of 300 individuals. Holothuria santorii was the most abundant species, with a total of 207 individuals; Holothuria dakarensis and Holothuria arguinensis were in lower abundance, with a total of 83 and 10 individuals, respectively. In the same way, Holothuria santorii was recorded in the $75 \%$ of surveyed sites, whereas Holothuria dakarensis and Holothuria arguinensis were observed in the 29 and $16 \%$ of sites, 
respectively. Mean abundances of each species at each site within each type of habitat and island are shown in Table 1. The mean total abundances of holothurians ranged

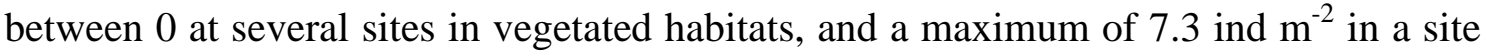
within 'barrens'. Mean total abundances of holothurians were 5 - 46 times more abundant at 'barrens' than at vegetated sites. Figure 1 illustrates the differences in the total accumulated abundances at each habitat for the total study. These striking differences in the abundances of holothurians between the 'barrens' and the three vegetated habitats were indicated by the PERMANOVA (main factor "Habitat", $p<$ 0.01, Table 2). However, the results were clearly species-specific. The mean abundance of the dominant species, Holothuria santorii, was consistently larger in the 'barrens' compared with the three vegetated habitats at both islands (Fig. 2), which was confirmed by the ANOVA ("Habitat”, $p<0.001$, Table 2) and the $a$ posteriori SNK tests (Fig. 2). Similarly, the mean abundance of Holothuria dakarensis was larger in the 'barrens' compared with the three vegetated habitats at Gran Canaria, but it did not occur at Tenerife (Fig. 2). This result was evidenced by the inconsistency detected by the 3-way ANOVA in the differences between habitats from one island to the other ("I $\mathrm{x}$ H”, $p<0.01$, Table 2). Indeed, no specimen of this species was found at Tenerife. Finally, mean abundances of Holothuria arguinensis did not differ between habitats at both islands (Figure 2), as indicated by the ANOVA ("Habitat" and "H x I", $p>0.01$, Table 2). We detected substantial spatial heterogeneity at the smallest spatial-scale (differences among replicated sites, 10s of km apart, within each habitat and island) for the three species and the whole assemblage (“Site ( $\mathrm{I} \times \mathrm{H})$ ), $p<0.01$, Table 2). Probably, the detection of considerable spatial heterogeneity at this scale masked the observation of significant inter-habitat differences for the less abundant species. 
In general, the total abundances of holothurians tended to increase with increasing the abundances of Diadema antillarum sea urchins within 'barrens' (Fig. 3, $\left.R^{2}=0.20 ; F=20.16, p<0.00001\right)$. Despite this relationship was statistically significant at the $99 \%$ confidence level, the $R^{2}$ statistic indicates that the model explains only around $20 \%$ of the variability in the total abundance of holothurians.

\section{Discussion}

In contrast to many temperate and tropical regions, holothurians inhabiting shallow bottoms are not exploited across the Canarian Archipelago. Subsequently, these animals can be found at high densities, as those reported by our results. This study provides correlative evidence to partially support the stated hypothesis: in general, 'barrens' with high densities of long-spined black sea urchins, Diadema antillarum, supported a higher abundance of holothurians compared with each of the three vegetated habitats. This difference was consistent between islands for the most abundant species, Holothuria sanctorii, which represented the $69 \%$ of the individuals. However, this pattern was not consistent for the less abundant species (Holothuria dakarensis and Holothuria arguinensis). As a result, the acceptance / rejection of the stated hypotheses were clearly species-specific.

To our knowledge, no study has quantitatively analyzed differences in the abundances of holothurians across a set of shallow-water habitats; comparisons with similar studies are thus limited. Our results suggest the existence of a link between the distribution and abundances of some species of holothurians and the type of habitat at shallow rocky reefs. This fact could be related to variations in the availability of POM across the studied habitats. The presence of high densities of sea urchins at 'barrens' likely produces important amounts of urchin-produced fecal pellets, as a source of fresh 
POM into the benthic system (Lawrence, 1976; Wotton, 1994; Lawrence \& Klinger, 2001; Levinton et al., 2002; Mamelona \& Pelletier, 2005). In general, sea urchins release $>60 \%$ of the ingested biomass as fecal matter, and detritivores probably use this as a food source (Wotton, 1994; Mamelona \& Pelletier, 2005). In the particular case of Diadema antillarum, this species produces globular fecal pellets measuring about 1-3 mm in diameter (Ogden \& Carpenter, 1987).

Diadema antillarum is directly involved in the transformation of large rocky reefs covered by erect algae to overgrazed, unvegetated, substrates dominated by encrusting organisms. Despite a lack of historical records and experimental evidence, hyperabundances of sea urchins are usually attributed to overexploitation of apex predators, following the classical tri-trophic food web trophic cascades paradigm (reviewed by Pinnegar et al., 2000). In particular, correlative evidence supports this hypothesis in the warm temperate waters of the eastern Atlantic (Alves et al., 2001; Tuya et al., 2004). As a result, mosaics of alternate organizational states on subtidal rocky reefs (vegetated versus unvegetated barren systems) occur widely across the eastern Atlantic. Here, we suggest another plausible third-order change occurs as a consequence of this trophic cascade.

Of course, our investigation neither measured in situ the amounts of POM, nor assessed the abundances across large spatial scales over long time periods; this observational study is a simplistic conceptualization of the potential interactions between holothurians and the type of habitat at shallow waters. Thus, the drawback of our approach is that habitats may differ in other respects than the availability of POM. For example, the wave-induced sweeping motion of large, canopy-forming, fucoid algae apparently may restrict the movement and suitable space to holothurians, as it has been 
largely observed for sea urchins in temperate waters (Konar, 2000; Gagnon et al., 2004; Tuya et al., 2005).

Settlement and recruitment processes probably affect the distribution and abundance of these invertebrates (Lewis, 1986; Balch \& Scheibling, 2001, and references therein), but inter-habitat migrations could also play a major role determining their spatial patterns. Settlement experiments in 'barrens' at the Canary Islands (Hernández et al., 2006) did not provide evidence of any event of settlement of holothurians over two years (Hernández, unpublished data); we thus wonder where holothurians settle. These observations fit with those reported from the Salomon Islands, where a size-specific distribution pattern has been described for Holothuria scabra. Large individuals ( $>10 \mathrm{~mm}$ ) were exclusively found on soft substrates, whereas newly settled juveniles appeared to occur on the leaves of seagrasses adjacent to adult populations (Mercier et al., 2000). Hence, holothurians may have high selectivity of substrates upon settlement. The lack of juveniles observed across 'barrens' by means of our personal direct and indirect observations (settlement devices, Hernández et al., 2006) could suggest that holothurians migrate from nearby habitats to the urchindominated reefs. While our observational findings and speculations are intriguing, future research at both small and large spatial scales over larger time periods will be necessary to asses the potential effect of the type habitat on the distribution of holothurians. Similarly, the possible inter-habitat connectivity in the life-cycles of shallow waters holothurians deserved attention.

In summary, our results encourage the development of similar surveys and experiments to test the generality of this patterns across 'barrens' produced as a result of hyperabundances of other echinoid species at different temperate regions, addressing the potential mechanisms that are responsible for the differences in the abundance 
patterns of certain populations of holothurians along a suite of habitats across the shallow subtidal.

\section{Acknowledgements}

We thank Leo Ortega for her diving assistance. Corrections, ideas and comments by M.A. Vanderklift, J. Bayle, and A. Luque greatly improved previous drafts of this paper.

\section{References}

Anderson, M.J., 2004. PERMANOVA_2factor: a FORTRAN computer program for permutational multivariate analysis of variance (for any two-factor ANOVA design) using permutation tests. Department of Statistics, University of Auckland, New Zealand.

Alves, F.M.A., L.M. Chicharo, E. Serrao \& A.D. Abreu, 2001. Algal cover and seaurchin spatial distribution at Madeira Island (NE Atlantic). Scientia Marina 65: 383392.

Andrew, N.L. \& A.J. Underwood, 1989. Patterns of abundance of the sea urchin Centrostephanus rodgersii (Agassiz) on the central coast of New South Wales, Australia. Journal of Experimental Marine Biology and Ecology 131: 61-80.

Balch, T. \& R.E. Scheibling, 2001. Larval supply, settlement and recruitment in echinoderms. In Jangoux, M. \& J.M. Lawrence (eds), Echinoderm studies, Volume 6, AA Balkema, The Netherlands. 
Benedetti-Cecchi, L., F. Bulleri \& F. Cinelli, 1998. Density dependent foraging of seaurchins in shallow subtidal reefs on the west coast of Italy (western Mediterranean). Marine Ecology Progress Series 163: 203-211.

Behrens, M.D. \& K.D. Lafferty, 2004. Effects of marine reserves and urchin disease on southern Californian rocky reef communities. Marine Ecology Progress Series 279: 129-139.

Frantzis, A. \& A. Gremare, 1992. Ingestion, absorption, and growth rates of Paracentrotus lividus (Echinodermata, Echinoidea) fed different macrophytes. Marine Ecology Progress Series 95: 169-183.

Gagnon, P., J.H. Himmelman \& L.E. Johnson, 2004. Temporal variation in community interfaces: kelp-bed boundary dynamics adjacent to persistent urchin barrens. Marine Biology 144: 1191-1203.

Ginger, M.L., D.S.M Billett, K.L. Mackenzie, K. Kiriakoulakis, R.R. Into, D.K. Boardman, V.C.L.S. Santos, I.M. Horsfall \& G.A. Wolff, 2001. Organic matter assimilation and selective feeding by holothurians in the deep sea: some observations and comments. Progress in Oceanography 50: 407-421.

Graham, M.H., 2004. Effects of local deforestation of the diversity and structure of southern California giant kelp forest food webs. Ecosystems 7: 341-357. 
Hammond, L.S., 1982. Patterns of feeding and activity in deposit-feeding holothurians and echinoids (Echinodermata) from a shallow Back-reef Lagoon, Discovery Bay, Jamaica. Bulletin of Marine Science 32: 549-571.

Hernández, J.C., A. Brito, E. Cubero, D. Girard, G. González-Lorenzo \& J.M. Falcón, 2006. Temporal pattern of larval settlement of Diadema antillarum (Echinodermata: Echinoidea) in the Canary Islands using and experimental larval collector. Bulletin of Marine Science 78: 271-279.

Knowlton, N., 2004. Multiple "stable" states and the conservation of marine ecosystems. Progress in Oceanography 60: 387-396.

Koike, I., H. Mukai \& S. Nojima, 1987. The role of the sea urchin, Tripneustes gratilla (Linnaeus), in decomposition and nutrient recycling in a tropical seagrass bed. Ecological Research 2: 19-29.

Konar, B., 2000. Seasonal inhibitory affects of marine plants on sea urchins: structuring communities the algal way. Oecologia 125: 208-217.

Lawrence, J.M., 1975. On the relationships between marine plants and sea-urchins. Oceanography and Marine Biology Annual Review 13: 213-286.

Lawrence, J.M., 1976. Absorption efficiencies of fur species of tropical echinoids fed Thallasia testidium. Thalass Jugosl 12: 201-205. 
Lawrence, J.M. \& T.S. Klinger, 2001. Digestion in sea urchins. In Lawrence, J.M. (ed), Edible Sea Urchins: Biology and Ecology: 103-113.

Lewin, R., 1986. Supply-side ecology. Science 234: 25-27.

Levinton, J.S., J.E. Ward \& S.E. Shumway, 2002. Feeding response of the bivalves Crassotrea gigas and Mytilus trossulus to chemical composition of fresh and aged kelp detritus. Marine Biology 141: 367-376.

Lison de Loma, T., M. Harmelin-Vivien, O. Naim \& M.F. Fontaine, 2000. Algal food processing by Stegastes nigricans, an herbivorous damselfish: differences between an undisturbed and a disturbed coral reef site (La Reunion, Indian Ocean. Oceanologia Acta 23: 793-804.

Mann, K.H., 1982. Kelp, sea-urchins and predators: a review of strong interactions in rocky subtidal systems of eastern Canada, 1970-1980. Netherlands Journal of Sea Research 16: 414-423.

Mamelona, J. \& E. Pelletier, 2005. Green urchin as a significant source of fecal particulate organic matter within nearshore benthic ecosystems. Journal of Experimental Marine Biology and Ecology 314: 163-174.

Massin, C., 1982. Effects of feeding on the environment: holothuroidea. In Jangoux, M. \& J.M. Lawrence (eds). Echinoderm Nutrition: 493-497. 
Mercier, A., S.C. Battaglene \& J.F. Hamel, 2000. Settlement preferences and early migration of the tropical sea cucumber Holothuria scabra. Journal of Experimental Marine Biology and Ecology 249: 89-110.

Mills, S.C., A. Peyrot-Clausada \& M.F. Fontaine, 2000. Ingestion and transformation of algal turf by Echinometra mathaei on Tiahura fringing reef (French Polynesia). Journal of Experimental Marine Biology and Ecology 254: 71-84.

Moriarty, D.J.W., 1982. Feeding of Holothuria atra and Stichopus chloronotus on bacteria, organic carbon and organic nitrogen in sediments of the Great Barrier Reef. Australian Journal of Marine and Freshwater Research 33: 255-263.

Mukai, H. \& S. Nojima, 1985. A preliminary study on grazing and defecation rate of a seagrass grazer, Tripneustes gratilla (Echinodermata: Echinoidea) in a Papua New Guinean seagrass bed. Special Publications of the Mukaishima Marine Biology Station: 173-183.

Ogden, J.C. \& R.C. Carpenter, 1987. Species profiles: life histories and environmental requirements of coastal fishes and invertebrates (south Florida) -the long-spine black sea urchin. US Fish and Wildlife Service Biological Report 82 (11.77). U.S. Army Corps of Engineers, TR El-82-4.

Pinnegar, J.K., N.V.C. Polunin, P. Francour, F. Badalamenti, R. Chemello, M.L. Harmelin-Vivien, B. Hereu, M. Milazo, M. Zabala, G. D’Anna \& C. Pipitone, 2000. 
Trophic cascades in benthic marine ecosystems: lessons for fisheries and protected-area management. Environmental Conservation 27: 179-200.

Ruitton, S., P. Francour \& C.F. Boudouresque, 2000. Relationships between algae, benthic herbivorous invertebrates and fishes in rocky sublittoral communities of a temperate sea (Mediterranean). Estuarine, Coastal and Shelf Science 50: 217-230.

Sala, E., C.F. Boudouresque \& M. L. Harmelin-Vivien, 1998. Fishing, trophic cascades, and the structure of algal assemblages: evaluation of an old but untested paradigm. Oikos 83: $425-439$.

Shears, N. T. \& R. C. Babcock, 2003. Continuing trophic cascades effects after 25 years on no-take marine reserve protection. Marine Ecology Progress Series 246: 1-16.

Steneck, R.S. \& M.N. Dethier, 1994. A functional group approach to the structure of algal-dominated communities. Oikos 69: 476-498.

Tuya, F., A. Boyra, P. Sanchez-Jerez, C. Barbera \& R.J. Haroun, 2004. Relationships between rocky-reef fish assemblages, the sea urchin Diadema antillarum and macroalgae throughout the Canarian Archipelago. Marine Ecology Progress Series 278: 157-169.

Tuya, F., P. Sanchez-Jerez \& R.J. Haroun, 2005. Factors affecting interfaces between algal assemblages and urchin barrens in the eastern Atlantic: the role of functional grouping level of dominant algae. Marine Ecology Progress Series 287: 255-260. 
Tuya, F. \& R.J Haroun, 2006. Spatial patterns and response to wave exposure of shallow water algal assemblages across the Canarian Archipelago: a multiscaled approach. Marine Ecology Progress Series 311: 15-28.

Underwood, A.J., 1997. Experiments in Ecology: their logical design and interpretation using Analysis of Variance. Cambridge University Press, Cambridge.

Uthicke, S., 2001. Nutrient regeneration by abundant coral reef holothurians. Journal of Experimental Marine Biology and Ecology 265: 153 - 170.

Vadas, R.L., 1977. Preferential feeding: an optimization strategy in sea urchins. Ecological Monographs 47: 337-371.

Wotton, R.S., 1994. The classification of particulate and dissolved matter. In Wotton, R.S. (ed). The biology of particles in aquatic systems: 1-6.

Yingst, J.Y., 1976. The utilization of organic matter in shallow marine sediments by an epibenthic deposit feeding holothurian. Journal of Experimental Marine Biology and Ecology 23: 55-69. 
Table 1. Mean abundances $\pm \mathrm{SE}$ (ind $\mathrm{m}^{-2}$ ) of holothurians at each site within each habitat and island.

\begin{tabular}{|c|c|c|c|c|c|c|}
\hline Island & Habitat & Site & H. sanctorii & H. arguinensis & H. dakarensis & Total Holothurians \\
\hline \multirow[t]{14}{*}{ Gran Canaria } & Barren & 1 & $1.9 \pm 0.23$ & $0.5 \pm 0.16$ & $1.0 \pm 0.36$ & $3.4 \pm 0.54$ \\
\hline & & 2 & $4.6 \pm 0.47$ & $0.1 \pm 0.10$ & $2.6 \pm 0.45$ & $7.3 \pm 0.70$ \\
\hline & & 3 & $3.9 \pm 1.21$ & 0 & $3.2 \pm 0.61$ & $7.1 \pm 0.72$ \\
\hline & Brown & & & & & \\
\hline & Macrophytes & 1 & $0.1 \pm 0.31$ & 0 & 0 & $0.1 \pm 0.31$ \\
\hline & & 2 & 0 & 0 & 0 & 0 \\
\hline & & 3 & 0 & 0 & 0 & 0 \\
\hline & Bush-like & & & & & \\
\hline & Algae & 1 & $0.2 \pm 0.13$ & $0.3 \pm 0.15$ & $0.1 \pm 0.10$ & $0.6 \pm 0.22$ \\
\hline & & 2 & $0.3 \pm 0.21$ & 0 & $0.7 \pm 0.39$ & $1.0 \pm 0.44$ \\
\hline & & 3 & $0.6 \pm 0.22$ & $0.1 \pm 0.10$ & $0.6 \pm 0.26$ & $1.3 \pm 0.39$ \\
\hline & Turf-Algae & 1 & $0.1 \pm 0.10$ & 0 & 0 & $0.1 \pm 0.10$ \\
\hline & & 2 & 0 & 0 & 0 & 0 \\
\hline & & 3 & $0.3 \pm 0.15$ & 0 & $0.1 \pm 0.10$ & $0.4 \pm 0.22$ \\
\hline \multirow[t]{14}{*}{ Tenerife } & Barren & 1 & $3.6 \pm 0.79$ & 0 & 0 & $3.6 \pm 0.79$ \\
\hline & & 2 & $0.9 \pm 0.23$ & 0 & 0 & $0.9 \pm 0.23$ \\
\hline & & 3 & $0.8 \pm 0.24$ & 0 & 0 & $0.8 \pm 0.24$ \\
\hline & Brown & & & & & \\
\hline & Macrophytes & 1 & $0.4 \pm 0.22$ & 0 & 0 & $0.4 \pm 0.22$ \\
\hline & & 2 & 0 & 0 & 0 & 0 \\
\hline & & 3 & 0 & 0 & 0 & 0 \\
\hline & Bush-like & & & & & \\
\hline & Algae & 1 & $0.8 \pm 0.32$ & 0 & 0 & $0.8 \pm 0.32$ \\
\hline & & 2 & $0.7 \pm 0.33$ & 0 & 0 & $0.7 \pm 0.33$ \\
\hline & & 3 & $0.3 \pm 0.15$ & 0 & 0 & $0.3 \pm 0.15$ \\
\hline & Turf-Algae & 1 & 0 & 0 & 0 & 0 \\
\hline & & 2 & $0.4 \pm 0.22$ & 0 & 0 & $0.4 \pm 0.22$ \\
\hline & & 3 & $0.8 \pm 0.29$ & 0 & 0 & $0.8 \pm 0.29$ \\
\hline
\end{tabular}


Table 2. Analysis of the effects of Islands (fixed), Habitats (fixed and orthogonal), and Sites (random and nested within each island and type of habitat) on the multivariate holothurian assemblage, as well as on each holothurian species. $p$-values were obtained using 4999 random permutations for the PERMANOVA. *: $p<0.01,{ }^{* *}: p<0.001$.

\begin{tabular}{|c|c|c|c|c|c|c|c|c|c|}
\hline \multirow[b]{3}{*}{ Source of variation } & \multirow[b]{3}{*}{ df } & \multicolumn{2}{|c|}{ PERMANOVA } & \multicolumn{6}{|c|}{ ANOVA } \\
\hline & & \multirow[b]{2}{*}{ MS } & \multirow[b]{2}{*}{$F$} & \multicolumn{2}{|c|}{ H. arguinensis } & \multicolumn{2}{|c|}{ H. dakarensis } & \multicolumn{2}{|c|}{ H. sanctorii } \\
\hline & & & & MS & $F$ & MS & $F$ & MS & $\mathrm{F}$ \\
\hline Island = I & 1 & 1410.13 & 4.16 & 0.20 & 3.57 & 6.37 & $26.43 * *$ & 0.33 & 0.56 \\
\hline Habitat $=\mathrm{H}$ & 3 & 67079.19 & $7.92 *$ & 0.07 & 1.00 & 3.38 & 1.00 & 14.06 & $7.02 *$ \\
\hline Site (I x H) & 16 & 3366.76 & $2.08^{*}$ & 0.05 & $3.94 * *$ & 0.24 & $14.03^{* *}$ & 0.59 & $4.86^{* *}$ \\
\hline $\mathrm{I} \times \mathrm{H}$ & 3 & 8459.24 & 2.51 & 0.07 & 1.29 & 3.38 & $14.03 * *$ & 2.00 & 3.37 \\
\hline Residual & 216 & 1615.54 & & 0.01 & & 0.06 & & 0.12 & \\
\hline
\end{tabular}


Legends to the figures:

Figure 1. Total abundance of each holothurian species at each habitat for the entire study.

Figure 2. Mean abundance of each holothurian species at each habitat and island. Error bars are standard errors of mean values. The acronyms of the SNK tests are: BLA (Bush-like Algae), TA (Turf Algae), BM (Brown Macrophytes).

Figure 3. Linear regression between the total abundances of holothurians and Diadema antillarum sea urchins across ‘barren’ sites of the Canarian Archipelago. 